\title{
Influence of Chromium Concentration on the Abrasive Wear of Ni-Cr-B-Si Coatings Applied by Supersonic Flame Jet (HVOF)
}

\author{
Mara Kandeva ${ }^{1,2}$, Zhetcho Kalitchin ${ }^{3, *}$ and Yana Stoyanova ${ }^{1}$ \\ 1 Tribology Center, Faculty of Industrial Engineering, Technical University-Sofia, 8 Kl. Ohridski Blvd, \\ 1757 Sofia, Bulgaria; kandevam@gmail.com (M.K.); yast@tu-sofia.bg (Y.S.) \\ 2 South Ural State University, 76 Prospekt Lenina, 454080 Chelyabinsk, Russia \\ 3 SciBuCom 2 Ltd., P.O. Box 249, 1113 Sofia, Bulgaria \\ * Correspondence: kalitchin@gmail.com
}

check for updates

Citation: Kandeva, M.; Kalitchin, Z.; Stoyanova, Y. Influence of Chromium Concentration on the Abrasive Wear of Ni-Cr-B-Si Coatings Applied by Supersonic Flame Jet (HVOF). Metals 2021, 11, 915. https://doi.org/ 10.3390/met11060915

Academic Editor: Jianqiang Wang

Received: 20 April 2021

Accepted: 25 May 2021

Published: 4 June 2021

Publisher's Note: MDPI stays neutral with regard to jurisdictional claims in published maps and institutional affiliations.

Copyright: (c) 2021 by the authors. Licensee MDPI, Basel, Switzerland. This article is an open access article distributed under the terms and conditions of the Creative Commons Attribution (CC BY) license (https:// creativecommons.org/licenses/by/ $4.0 /)$.

\begin{abstract}
This research work studies the characteristics of wear and wear resistance of composite powder coatings, deposited by supersonic flame jet (HVOF), which contain composite mixtures Ni-Cr-B-Si having different chromium concentrations-9.9\%,13.2\%,14\%,16\%, and $20 \%$, at one and the same size of the particles and the same content of the remaining elements. The coating of $20 \%$ $\mathrm{Cr}$ does not contain B and Si. Out of each powder composite, coatings have been prepared without any preliminary thermal treatment of the substrate and with preliminary thermal treatment of the substrate up to $650{ }^{\circ} \mathrm{C}$. The coatings have been tested under identical conditions of dry friction over a surface of solid, firmly-attached, abrasive particles using tribological testing device "Pin-on-disk". Results have been obtained and the dependences of the hardness, mass wear, intensity of the wearing process, and absolute and relative wear resistance on the $\mathrm{Cr}$ concentration under identical conditions of friction. It has been found out that for all the coatings the preliminary thermal treatment of the substrate leads to a decrease in the wear intensity. Upon increasing $\mathrm{Cr}$ concentration the wear intensity diminishes and it reaches minimal values at $16 \% \mathrm{Cr}$. In the case of coatings having $20 \%$ $\mathrm{Cr}$ concentration, the wear intensity is increased, which is due to the absence of the components $\mathrm{B}$ and $\mathrm{Si}$ in the composite mixture, whereupon no inter-metallic structures are formed having high hardness and wear resistance. The obtained results have no analogues in the current literature and they have not been published by the authors.
\end{abstract}

Keywords: HVOF coatings; chromium; tribology; abrasion wear

\section{Introduction}

The basic priorities of contemporary engineering science and practice refer to enhancement of energy effectiveness and functionality of the industrial systems in harmonic coexistence with clean environment, preservation of natural resources, and improving of the quality of life. These priorities are connected with the genesis of tribology as contemporary science and technology for contact processes of friction, wear, and greasing in the technical systems [1-3]. The lowering of the wear intensity in the machines appears to be the central task of tribology tribological technologies. It is the reason for more than $85 \%$ of the machine failures, huge expenses of materials, and human resources for spare parts, consumables, and expenses for maintenance in the process of operation. The decrease in the wear intensity results not only in lower financial expenses, but also decrease in extraction of raw materials from the natural environment, which is directly connected with the equilibrium in eco-systems [4-10].

The abrasive and erosive wear are the most dangerous types of wear in the machines for ore mining, road construction, agricultural technique, energy production, transportation, aircraft building, and space technology. They are the reason for more than $50 \%$ of all the technical failures due to wear of machine components and the expenses due to it in the world reach $1-4 \%$ of the gross domestic product GDP of the developed industrial countries 
in the world. The problem of abrasive and erosive wear resistance of tribological materials is of exceptional importance and actuality, which is evidenced by the fact that there exist 17 active standards ASTM, concerning the abrasive wear and at least 4 standards connected with the erosion wear.

It is of special importance for the high wear resistance of tribology materials to combine high hardness and plasticity, which are mutually self-excluding aspects and they cannot be achieved by most of the conventional tribology technologies [11-24].

The composite powder coatings, deposited by means of supersonic flame jet-HVOF (High Velocity Oxy-Fuel) are a new generation of tribo-materials, allowing to achieve a wide range of combining mechanical and tribological characteristics-high adhesion strength, density, hardness, wear resistance, and corrosion stability. The powder particles obtain high kinetic and thermal energy in the flame jet, passing over into semi-plastic and/or plastic state in the form of droplets or particles, and they interact with the substrate being deformed, whereupon they form thin lamellas. Upon their collision with roughness of the substrate the particles' droplets are being cooled down, forming adhesion bonds with the surface, and cohesion bonds between each other leading to generation of the laminar structure of the composite coating. Due to the high velocity and low contact time of the particles with oxygen under definite conditions they do not form oxides, which, in fact, is a prerequisite for good tribological properties of the coatings $[25,26]$. HVOF-coatings are the object of intensive investigations and they are continuously being improved [27-41]. The results of studies of the authors and those of other researchers show that the mechanical and tribological characteristics of the HVOF-coatings, depend not only on the parameters of the technological regime of deposition, but also to a great extent they depend on the chemical composition and on the concentrations of the chemical elements in the powder composite material, the size of the particles, and on the temperature of the substrate. The results also depend on the type and the dimensions of the contact (point type, linear type, planar type) $[29,31,35]$. The papers $[35,36]$ present interesting results concerning the ceramic coatings with aluminum oxide matrix $\left(\mathrm{Al}_{2} \mathrm{O}_{3}\right)$ with matrix of $3 \%$ titanium oxide $\left(\mathrm{TiO}_{2}\right)$ and zirconium oxide $\left(\mathrm{ZrO}_{2}\right)$ matrix with $30 \%$ calcium oxide $(\mathrm{CaO})$ on the basis of non-alloy structural steel of the S235JR class. The buffer layer is obtained on the basis of Ni-Al-Mo powder. The complex investigations including metallographic tests, phase composition, microhardness, adhesion of coating to the base, resistance to abrasion, and heat shock show that these coatings have high abrasive and erosion wear resistance and resistance towards thermal impact load. In the paper [37] the results of the investigation of the mechanical properties of aluminum coatings are presented by the same Authors. The coatings are strengthened with carbon materials with nano-dimensions: carbon nanotubes Nanocyl NC $7000(0.5 \mathrm{w} . \%$ and $1 \mathrm{w} . \%)$ and (carburate $0.5 \mathrm{w} . \%)$. It has been proved that the applied coatings with nano-carbon particles, will be an effective alternative of coatings applied with laser technology and might be additionally improved and successfully applied in the automotive, aviation, and space technology.

According to the specialized literature the most widely used in the practice high quality powder metal composites, known as "super alloys", can be divided into two large groups: powder composites based on nickel (nickel-chromium-boron-silicon (Ni-CrB-Si)) and powder composites based on cobalt (tungsten-cobalt-chromium alloys). The chromium at high temperatures is involved into contact interactions with the carbon, silicon, and boron, whereupon it forms new inter-metallic structures. It forms with the carbon solid high-melting structure $\left(\mathrm{Cr}_{3} \mathrm{C}_{2}\right)$ having a green color, which is not dissolved in acids and which attributes to the coating high corrosion stability. Chromium forms with the oxygen some oxides $\left(\mathrm{CrO}_{3}, \mathrm{Cr}_{2} \mathrm{O}_{3}\right)$, which are characterized by high level of hardness and fragility $[33,34]$.

In the paper [40], the influence of the dimensions of the abrasive particles has been presented on the abrasive stability on the coatings of $40 \mathrm{WC} / \mathrm{Co}$, applied by three technological regimes: high velocity oxygen fuel (HVOF), high energy plasma spray (HEPS), and high velocity plasma spray (HVPS) with the use of nanostructured experimental powders. 
The most important results are: first- the coatings applied by HVOF have the best wear resistance, while the HVPS coatings have the worst wear resistance; and second-the greater the size of the abrasive particles, the lower the abrasion resistance of the coatings.

Thermospray coatings based on tungsten, nickel, and their compounds are widely used in extreme operating conditions due to their high resistance to wear and oxidation at high temperatures [39-41]. Work [39] is an in-depth study of the influence of process primers on friction, abrasion resistance, and corrosion of U.Co coatings deposited on aluminum alloy AA 7050 by HVOF process.

The present publication represents the results from an investigation about the influence of chromium concentration on the abrasion wear of Ni-Cr-B-Si coatings, deposited by means of supersonic flame jet on a substrate with and without thermal treatment of the substrate.

\section{Materials and Technology}

The investigated coatings are obtained in the following consecutive steps: preparation of the powder compositions, preparation of the substrate, application of the coatings with HVOF technology, measurement of the thickness and the hardness of the obtained coatings, preparation of the samples for testing of the abrasive wear, and calculation of the characteristic of the wear (Figure 1).

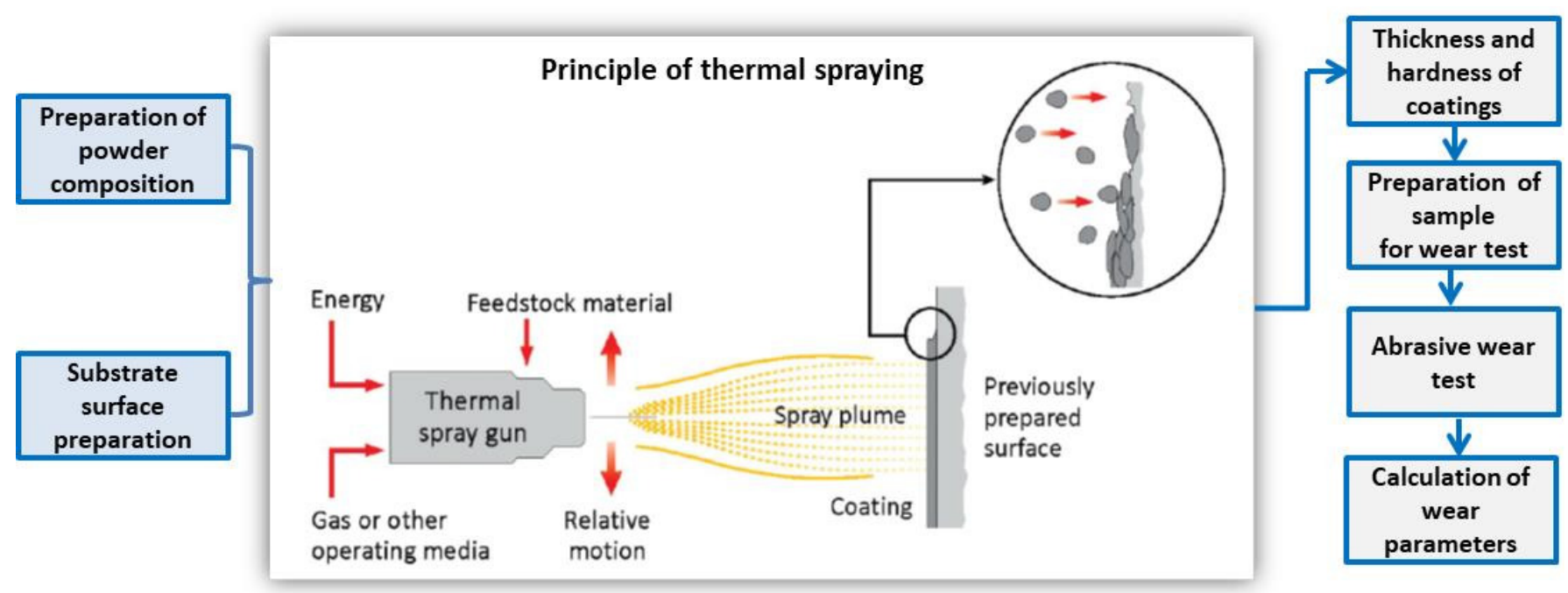

Figure 1. Scheme of preparation and research of HVOF-coatings.

Ten types of coatings were prepared on the basis of five composite powder mixtures with nickel matrix, united in five series $\mathrm{A}, \mathrm{B}, \mathrm{C}, \mathrm{D}, \mathrm{E}$ (Table 1). The serial composition A, B, C, D containing different concentration of Chromium-9.9\%, $13.2 \%, 14 \%, 16 \%$, and approximately the same composition of the other chemical elements- $\mathrm{Si}, \mathrm{B}, \mathrm{Fe}, \mathrm{Cu}$, Mo, etc. The composite mixture of series $\mathrm{E}$ (sample No 9 and No 10 ) contain $20 \% \mathrm{Cr}$ and $80 \% \mathrm{Ni}$, i.e., in it are not included other elements, present in the compositions A, B, C, D, respectively.

From each of the series, we applied two types of coatings; without preliminary thermic processing of the substrate (cold HVOF process); and with preliminary heating of the substrate in thermic chamber at a temperature of $650{ }^{\circ} \mathrm{C}$ for $60 \mathrm{~min}$. The coatings with thermic processing of the substrate are denoted with PHS.

All the coatings have been deposited on a substrate of one and the same materialsteel of chemical composition: C-0.15\%; S- $0.025 \%$; $\mathrm{Mn}-0.8 \%$; P-0.011\%; Si-0.21\%; $\mathrm{Cr}-0.3 \% ; \mathrm{Ni}-0.3 \%$ and hardness $193.6-219.5 \mathrm{HV}$.

The particles in all the powder composites have one and the same size $-45 \pm 2.5 \mu \mathrm{m}$. Before placing of the powder composite inside the system for thermal spraying, it is heated for $30 \mathrm{~min}$ at temperature $150^{\circ} \mathrm{C}$ in thermal chamber for removing the moisture and the other adsorbed organic molecules. 
Table 1. Description, chemical composition, hardness, and thickness of the tested coatings.

\begin{tabular}{|c|c|c|c|c|c|c|}
\hline Series & Sample & $\begin{array}{c}\text { Coating } \\
\text { Designation }\end{array}$ & Description & $\begin{array}{c}\text { Chemical } \\
\text { Composition, wt. } \%\end{array}$ & $\begin{array}{l}\text { Hardness } \\
\text { HRC }\end{array}$ & $\begin{array}{c}\text { Thickness } \\
\mu \mathrm{m}\end{array}$ \\
\hline \multirow{2}{*}{ A } & 1 & NiBSi-9.9Cr & $\begin{array}{l}\text { Coatings without heat } \\
\text { treatment of the substrate }\end{array}$ & \multirow{2}{*}{$\begin{array}{c}\text { Cr: 9.9; Si:3.1; B:1.7; } \\
\text { Fe:3.2; C: 0.35; Mo: 3; } \\
\text { Cu:3; } \\
\text { Ni Balance }\end{array}$} & $55-56$ & $410-415$ \\
\hline & 2 & $\begin{array}{l}\text { NiBSi- } \\
\text { 9.9Cr:PHS }\end{array}$ & $\begin{array}{l}\text { Coatings with heat } \\
\text { treatment of the substrate }\end{array}$ & & $58-59$ & $400-412$ \\
\hline \multirow{2}{*}{ B } & 3 & NiBSi-13.2Cr & $\begin{array}{l}\text { Coatings without heat } \\
\text { treatment of the substrate }\end{array}$ & \multirow{2}{*}{$\begin{array}{c}\text { Cr: 13.2; Si: 3.98; B: } \\
\text { 2.79; Fe: 4.6; Co: } 0.03 \text {; } \\
\text { C: } 0.63 ; \\
\text { Ni: Balance }\end{array}$} & $56-57$ & $395-400$ \\
\hline & 4 & $\begin{array}{l}\text { NiBSi- } \\
\text { 13.2Cr:PHS }\end{array}$ & $\begin{array}{l}\text { Coatings with heat } \\
\text { treatment of the substrate }\end{array}$ & & $59-60$ & $408-414$ \\
\hline \multirow{2}{*}{$\mathrm{C}$} & 5 & $\mathrm{NiBSi}-14 \mathrm{Cr}$ & $\begin{array}{l}\text { Coatings without heat } \\
\text { treatment of the substrate }\end{array}$ & \multirow{2}{*}{$\begin{array}{c}\text { Cr: 14; Si:4.2; B:2,9; } \\
\text { Fe:4,6; C:0.6; Mo:2,5; } \\
\text { Cu:2,4; } \\
\text { Ni: Balance }\end{array}$} & $57-58$ & $395-406$ \\
\hline & 6 & $\begin{array}{c}\text { NiBSi- } \\
\text { 14Cr:PHS }\end{array}$ & $\begin{array}{l}\text { Coatings with heat } \\
\text { treatment of the substrate }\end{array}$ & & $59-60$ & $400-405$ \\
\hline \multirow{2}{*}{$\mathrm{D}$} & 7 & NiBSi-16Cr & $\begin{array}{l}\text { Coatings without heat } \\
\text { treatment of the substrate }\end{array}$ & \multirow{2}{*}{$\begin{array}{c}\text { Cr:16; Si:4; B:3.4; } \\
\text { Fe:2.7; C:0.6; Mo:3; } \\
\text { Cu:3; } \\
\text { Ni: Balance }\end{array}$} & $58-59$ & $394-405$ \\
\hline & 8 & $\begin{array}{c}\text { NiBSi- } \\
\text { 16Cr:PHS }\end{array}$ & $\begin{array}{l}\text { Coatings with heat } \\
\text { treatment of the substrate }\end{array}$ & & $61-62$ & $404-410$ \\
\hline \multirow{2}{*}{$\mathrm{E}$} & 9 & $\mathrm{Ni80}-20 \mathrm{Cr}$ & $\begin{array}{l}\text { Coatings without heat } \\
\text { treatment of the substrate }\end{array}$ & \multirow{2}{*}{ Cr: 20; Ni: 80} & $54-55$ & $400-408$ \\
\hline & 10 & Ni80-20Cr:PHS & $\begin{array}{l}\text { Coatings with heat } \\
\text { treatment of the substrate }\end{array}$ & & $57-60$ & $393-403$ \\
\hline
\end{tabular}

In order to increase the adhesion strength of the coatings, the substrate is heated preliminarily in three stages: cleaning, erosion with abrasive particles (blasting), and mechanical treatment. The cleaning is aimed at the removal of mechanical contaminants, adsorbed organic molecules, moisture, and other components, and it is carried out using a solvent. The extraction of the adsorbed gas molecules and elements in the depth of the surface layer is achieved by burning of the surface of the substrate with a flame to reach $100{ }^{\circ} \mathrm{C}$ at a distance of the nozzle $40 \mathrm{~mm}$ and at an angle of $45^{\circ}$ or with vapor spraying device. After this operation, again the surface is cleaned with a solvent.

Upon erosion of the surface of the substrate (blasting) one can achieve a definite level of roughness of the substrate, which is of essential importance for the level of the adhesion strength of the coating. We used abrasive material "Grit", in accordance with the requirements of the standard ISO 11126, having granular composition of the abrasive material in the following percentage ratio: $3.15 \div 1.4 \mathrm{~mm}-9.32 \% ; 1.63 \div 0.5 \mathrm{~mm}-16.4 \%$; $1.4 \div 1.0 \mathrm{~mm}-15.8 \% ; 1.0 \div 0.63 \mathrm{~mm}-39.6 \% ; 0.5 \div 0.315 \mathrm{~mm}-9.32 \% ; 0.315 \div 0.16 \mathrm{~mm}-$ $9.32 \%$; particles having sizes below $0.15 \mathrm{~mm}$ of the various fractions-up to $100 \%$ of the following chemical compounds: $\mathrm{SiO}_{2}-41 \%$, combined in the form of silicates; $\mathrm{AlO}-8.3 \%$, $\mathrm{MgO}-6.6 \%, \mathrm{CaO}-5.5 \%$, and $\mathrm{MnO}-0.4 \%$.

The system for blasting has the following technical parameters: input pressure $8 \mathrm{~atm}$; operating pressure in the nozzle $-4 \mathrm{~atm}$; diameter of the nozzle $7 \mathrm{~mm}$; distance between the nozzle and the surface $-30 \mathrm{~mm}$; angle of interaction of the jet with the surface- $90^{\circ}$.

The coatings have been deposited using the device MICROJET + Hybrid, which makes use of fuel mixture of acetylene and oxygen. The parameters of the technological regime of deposition of the coatings are listed in Table 2. 
Table 2. Technological regime parameters for HVOF coating deposition.

\begin{tabular}{cc}
\hline Parameter & Technological Regime \\
\hline Propylene/oxygen ratio & $55 / 100 \%$ \\
\hline Particle velocity & $1000 \mathrm{~m} / \mathrm{s}$ \\
\hline Spraying distance & $100 \mathrm{~mm}$ \\
\hline Impact angle & $90^{\circ}$ \\
\hline Air pressure from compressor & $5 \mathrm{bar}$ \\
\hline $\mathrm{N}_{2}$ pressure in the proportioning device & $4 \mathrm{bar}$ \\
\hline Powder feed rate & $22 \mathrm{~g} / \mathrm{min}$ \\
\hline
\end{tabular}

In case of deposition of coatings without thermal treatment (cold HVOF process), the surface of the substrate is heated using flame having temperature up to $200{ }^{\circ} \mathrm{C}$, which is measured by Laser infrared thermometer INFRARED with an error of $0.5^{\circ} \mathrm{C}$.

The coating is deposited in several layers. In the case of the first layer the nozzle is situated at an angle of $45^{\circ}$ and at a distance from the substrate $10 \mathrm{~mm}$, while in the consecutive layers - at a distance of $25 \mathrm{~mm}$. Coatings have been prepared having thickness within the range from $393 \mu \mathrm{m}$ up to $415 \mu \mathrm{m}$. The thickness of the coatings is measured by a portable device Pocket Leptoskop 2021 Fe in 10 points on the surface and the mean arithmetic value is taken (Table 1). The accuracy of the apparatus is $1 \mu \mathrm{m}$.

After polishing all surfaces, the coatings have the same roughness $\mathrm{Ra}=0.450-0.455 \mu \mathrm{m}$, which is measured by recording the profile diagram using profile metering device "TESA Rugosurf 10-10G" with an error of $0.005 \mu \mathrm{m}$.

The hardness of the coatings is measured by hardness-metering device "Bambino" based on the scale of Rockwell (HRC) taking the mean arithmetic value out of three measurements for each sample in order to eliminate some possible effects of segregation.

\section{Experimental Procedures}

The abrasive wear of the coatings is studied under conditions of dry friction during sliding along the surface with firmly attached abrasive particles.

The methodology consists in measurement of the mass wear of the coatings after a definite pathway of friction (number of cycles) under set permanent conditions-loading, sliding velocity, kinds of the abrasive, temperature of the environment. The mass of the samples before and after a definite pathway of friction is measured by electric balance WPS $180 / \mathrm{C} / 2$ with an accuracy of $0.1 \mathrm{mg}$. In each experiment, with each sample, the abrasive surface is replaced and prior to each measurement the sample is cleaned, removing mechanical and organic particles, thereafter it is dried up using ethyl alcohol in order to prevent the electrostatic effect.

After measuring of the mass wear the wear process characteristics are calculatedreduced intensity of the wear process, the absolute or the relative wear resistance.

The mass wear in $\mathrm{mg}$ is obtained as the difference between the initial mass of the sample $m_{o}$ and its mass $m_{i}$ after a definite number of cycles of friction:

$$
m=m_{o}-m_{i}
$$

The wear rate of the wear process $i_{r}$ represents the mass wear $m$ of the coating per unit of loading $P$ and per unit of path length $L$ of friction. It is measured in $\mathrm{mg} / \mathrm{Nm}$ and it is estimated by the formula:

$$
i_{r}=\frac{m}{P L}
$$


The absolute abrasive wear resistance $I_{r}$ is represented as the reciprocal value of the reduced wear rate and it has dimension $\mathrm{Nm} / \mathrm{mg}$, i.e.,

$$
I_{r}=\frac{1}{i_{r}}=\frac{P L}{m}
$$

The relative wear resistance $R_{i j}$ is dimensionless quantity and it represents the ratio between the wear resistance of the tested sample $I_{r}^{i}$ and the wear resistance of a sample, taken as a standard $I_{r}^{j}$, determined during identical regimes of friction, i.e.,

$$
R_{i j}=\frac{I_{r}^{i}}{I_{r}^{j}}
$$

The abrasive wear is studied using tribological tester "Pin-on-disc" in case of planelike contact using the functional scheme, shown in Figure 2. The studied sample with coating 1 (pin) is firmly attached in the holder 2 of the loading head 8 , in such a way that the frontal surface of the sample is in contact with the abrasive surface 3 , fixed to a horizontal disc 4 . The disc 4 is driven by the electric motor 6 and it is rotating around its central vertical axis at constant angle velocity. The normal loading pressure $P$ is adjusted by means of the lever system in the center of the contact plate between the sample and the abrasive surface. The pathway length of friction as a number of cycles $(N)$ is selected and then measured by the turnover number metering device 7 . The abrasive surface 3 is modeled by impregnated corundum P 320 of hardness 9.0 on the scale of Moos, whereupon the requirement of the standard for minimum $60 \%$ higher hardness of the abrasive is observed with respect to that of the surface layer of the tested materials.

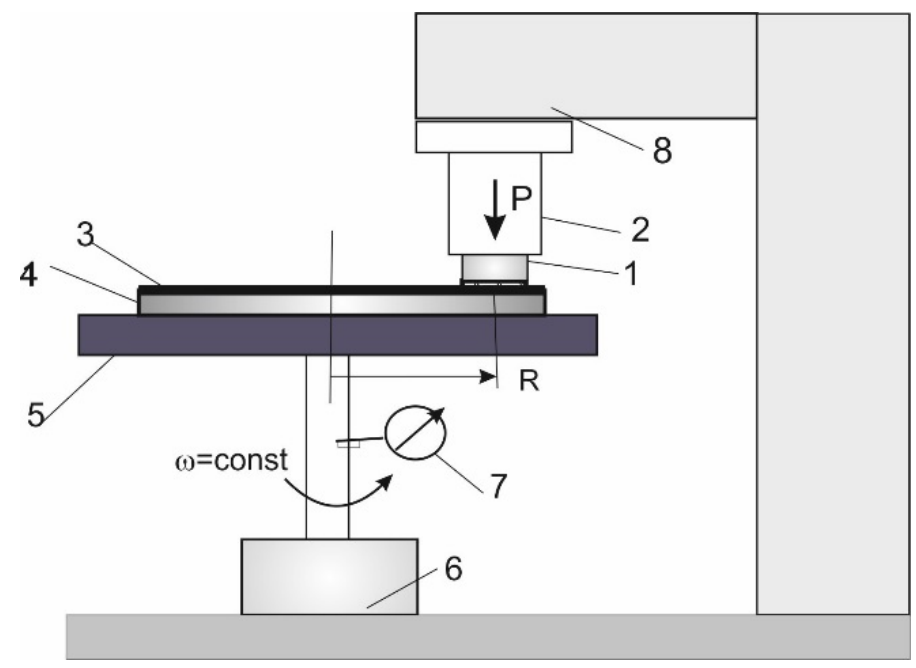

Figure 2. Schematic diagram of abrasive wear testing on pin-disc tribometer.

The investigation of all the coatings has been carried out using a set of the following parameters of the regime of friction: loading $4.5 \mathrm{~N}$, nominal contact surface area $2.25 \times 10^{-6} \mathrm{~m}^{2}$; nominal contact pressure $2.0 \mathrm{~N} / \mathrm{cm}^{2}$, sliding velocity of $0.155 \mathrm{~m} / \mathrm{s}$; type of the abrasive surface Corundum P 320 , temperature of the environment $21^{\circ} \mathrm{C}$.

\section{Experimental Results and Discussion}

Applying the above-described methodology and the device experimental results have been obtained for the mass wear process, the wear rate, and the absolute and the relative wear resistance for all the studied coatings, listed in Table 1.

In Table 3, we give the results of the mass wear rate at a friction path 20, 40, 60 and $80 \mathrm{~m}$. 
Table 3. Abrasive wear and wear rate of tested coatings.

\begin{tabular}{|c|c|c|c|c|c|}
\hline \multirow{5}{*}{ Sample } & \multirow{5}{*}{$\begin{array}{c}\text { Coating } \\
\text { Designation }\end{array}$} & \multicolumn{4}{|c|}{ Number of Cycles } \\
\hline & & 100 & 200 & 300 & 400 \\
\hline & & \multicolumn{4}{|c|}{ Sliding Distance, $\mathrm{m}$} \\
\hline & & 20 & 40 & 60 & 80 \\
\hline & & \multicolumn{4}{|c|}{ Mass Wear, [mg]//Wear Rate, [mg/Nm] } \\
\hline 1 & NiBSi-9.9Cr & $\begin{array}{c}4.7 \\
5.22 \times 10^{-2}\end{array}$ & $\begin{array}{c}8.5 \\
4.71 \times 10^{-2}\end{array}$ & $\begin{array}{c}12.7 \\
4.71 \times 10^{-2}\end{array}$ & $\begin{array}{c}15.3 \\
4.24 \times 10^{-2}\end{array}$ \\
\hline 2 & NiBSi-9.9Cr:PHS & $\begin{array}{c}3.2 \\
3.56 \times 10^{-2}\end{array}$ & $\begin{array}{c}5.8 \\
3.22 \times 10^{-2}\end{array}$ & $\begin{array}{c}11.2 \\
4.15 \times 10^{-2}\end{array}$ & $\begin{array}{c}12.6 \\
3.51 \times 10^{-2}\end{array}$ \\
\hline 3 & $\mathrm{NiBSi}-13.2 \mathrm{Cr}$ & $\begin{array}{c}4.4 \\
4.89 \times 10^{-2}\end{array}$ & $\begin{array}{c}7.9 \\
4.4 \times 10^{-2}\end{array}$ & $\begin{array}{c}10.6 \\
3.93 \times 10^{-2}\end{array}$ & $\begin{array}{c}12.3 \\
3.42 \times 10^{-2}\end{array}$ \\
\hline 4 & NiBSi-13.2Cr:PHS & $\begin{array}{c}3.5 \\
3.89 \times 10^{-2}\end{array}$ & $\begin{array}{c}7.1 \\
3.96 \times 10^{-2}\end{array}$ & $\begin{array}{c}9.8 \\
3.62 \times 10^{-2}\end{array}$ & $\begin{array}{c}10.4 \\
2.89 \times 10^{-2}\end{array}$ \\
\hline 5 & NiBSi-14Cr & $\begin{array}{c}4.0 \\
4.44 \times 10^{-2}\end{array}$ & $\begin{array}{c}6.0 \\
3.33 \times 10^{-2}\end{array}$ & $\begin{array}{c}7.6 \\
2.82 \times 10^{-2}\end{array}$ & $\begin{array}{c}10.5 \\
2.91 \times 10^{-2}\end{array}$ \\
\hline 6 & NiBSi-14Cr:PHS & $\begin{array}{c}3.1 \\
3.44 \times 10^{-2}\end{array}$ & $\begin{array}{c}4.2 \\
2.33 \times 10^{-2}\end{array}$ & $\begin{array}{c}5.8 \\
2.16 \times 10^{-2}\end{array}$ & $\begin{array}{c}7.6 \\
2.11 \times 10^{-2}\end{array}$ \\
\hline 7 & NiBSi-16Cr & $\begin{array}{c}1.5 \\
1.67 \times 10^{-2}\end{array}$ & $\begin{array}{c}2.2 \\
1.22 \times 10^{-2}\end{array}$ & $\begin{array}{c}2.8 \\
1.04 \times 10^{-2}\end{array}$ & $\begin{array}{c}3.3 \\
0.91 \times 10^{-2}\end{array}$ \\
\hline 8 & NiBSi-16Cr:PHS & $\begin{array}{c}0.9 \\
1.0 \times 10^{-2}\end{array}$ & $\begin{array}{c}1.2 \\
0.67 \times 10^{-2}\end{array}$ & $\begin{array}{c}1.6 \\
0.58 \times 10^{-2}\end{array}$ & $\begin{array}{c}1.8 \\
0.49 \times 10^{-2}\end{array}$ \\
\hline 9 & Ni80-20Cr & $\begin{array}{c}2.9 \\
3.22 \times 10^{-2}\end{array}$ & $\begin{array}{c}5.6 \\
3.11 \times 10^{-2}\end{array}$ & $\begin{array}{c}7.6 \\
2.82 \times 10^{-2}\end{array}$ & $\begin{array}{c}10.4 \\
2.89 \times 10^{-2} \\
\end{array}$ \\
\hline 10 & Ni80-20Cr:PHS & $\begin{array}{c}1.8 \\
2.0 \times 10^{-2}\end{array}$ & $\begin{array}{c}4.1 \\
2.22 \times 10^{-2}\end{array}$ & $\begin{array}{c}6.3 \\
2.33 \times 10^{-2}\end{array}$ & $\begin{array}{c}9.1 \\
2.51 \times 10^{-2}\end{array}$ \\
\hline
\end{tabular}

In accordance with the data in Table 3 the kinetic curves have been plotted in regard to the mass wear for all coatings with and without thermal treatment of the substrate, represented in the Figures 3-7. Each plotted graph represents regression equations of the wearing process as a function of the length of the friction pathway $m=m(L)$ and the value of the wear rate $i_{r}$ at friction pathway length $L=80 \mathrm{~m}$. It is seen, that in the case of dry abrasive friction, the dependence of the mass wear as a function of the sliding pathway has linear character for coatings with and without thermal treatment of the substrate.

The second observation in the analysis of these curves refers to the fact that the wear of all coatings having thermal treatment of the substrate is less than the wear of the coatings without any thermal treatment of the substrate.

Figure 8 represents graphically the dependence of the wear rate on the concentration of chromium for coatings without thermal treatment of the substrate and for coatings with thermal treatment of the substrate for one and the same friction pathway length $L=80 \mathrm{~m}$.

The curves have non-linear character with a clearly expressed minimum of the wear rate at $16 \%$ concentration of $\mathrm{Cr}$ for coatings with and without thermal treatment. In the first section, in which the chromium concentration is changing within the range from $9.9 \%$ to $16 \%$ upon increasing of the chromium concentration, the wear rate decreases down to reaching a minimal value at chromium concentration $16 \%$, respectively, for coatings without thermal treatment of the substrate $i_{r}=0.91 \times 10^{-2} \mathrm{mg} / \mathrm{Nm}$ and for coatings with thermal treatment of the substrate $i_{r}=0.49 \times 10^{-2} \mathrm{mg} / \mathrm{Nm}$. In the second section, at higher chromium concentration (20\%) (coatings Ni80-20Cr and Ni80-20Cr:PHS), the wear rate is increasing sharply. In spite of the higher chromium concentration the increase in the wear is due to the absence of the elements $\mathrm{B}, \mathrm{Si}, \mathrm{Cu}$, and the others, which are contained in the other coatings. These elements in the process of contact interaction of the flame jet with the substrate at the high temperature are forming inter-metallic compounds with the chromium, which lead to decrease in the wear rate. 


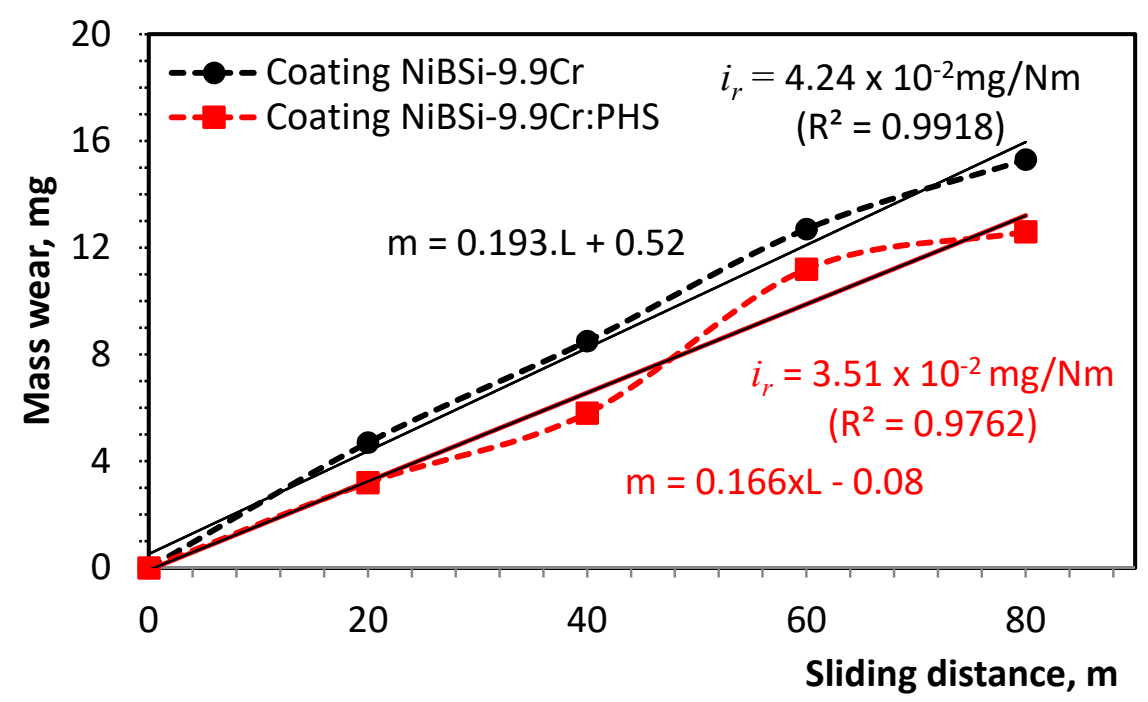

Figure 3. Mass wear vs. sliding distance for NiBSi-9.9Cr and NiBSi-9.9Cr: PHS coatings.

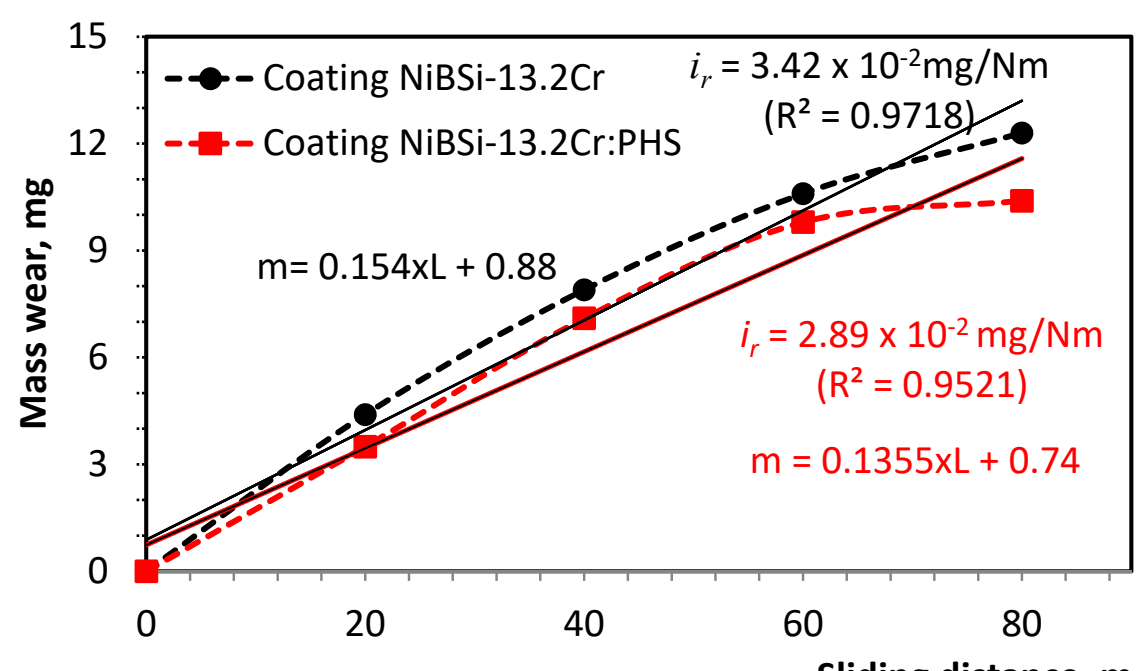

Figure 4. Mass wear vs. sliding distance for NiBSi-13.2Cr and NiBSi-13.2Cr: PHS coatings.

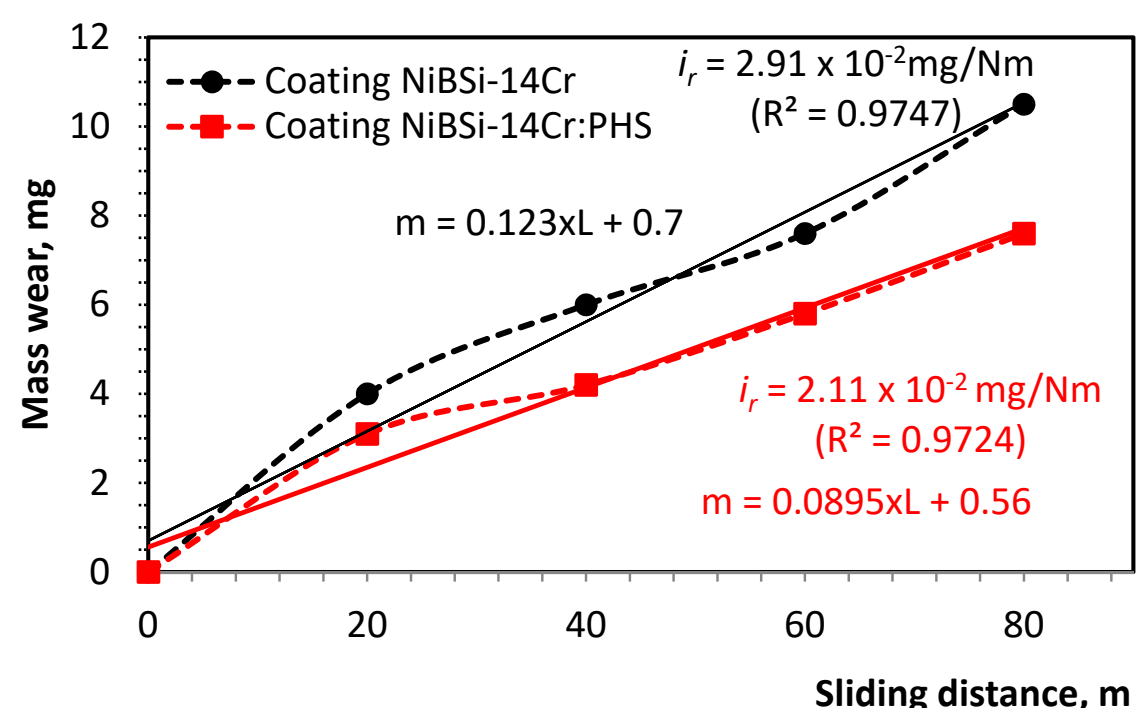

Figure 5. Mass wear vs. sliding distance for NiBSi-14Cr and NiBSi-14Cr: PHS coatings. 


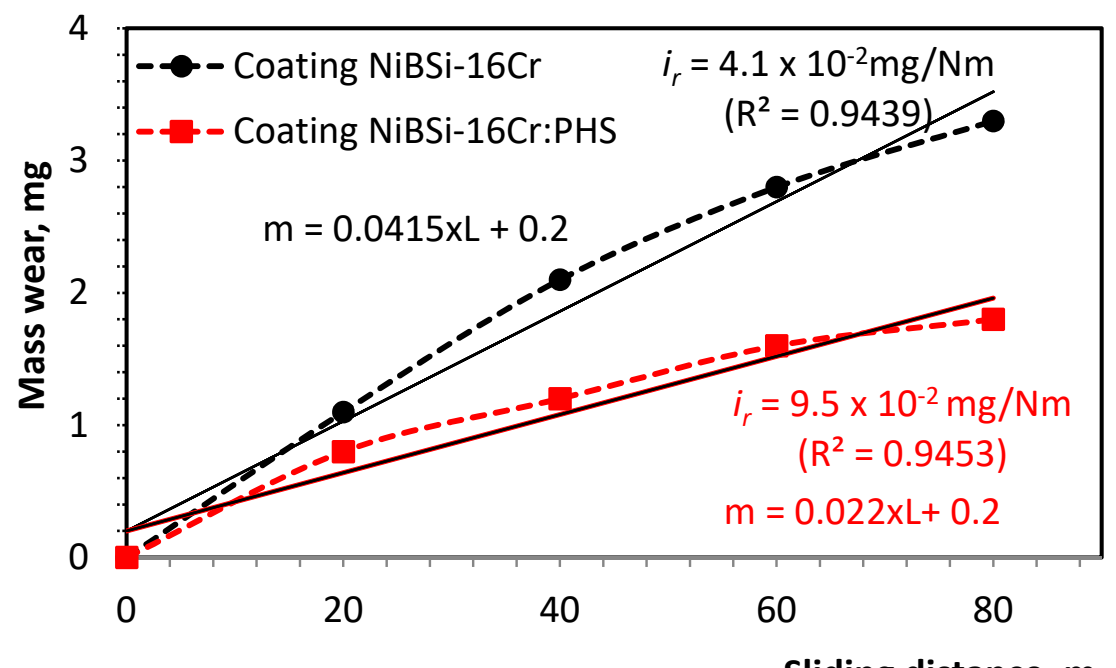

Figure 6. Mass wear vs. sliding distance for NiBSi-16Cr and NiBSi-16Cr: PHS coatings.

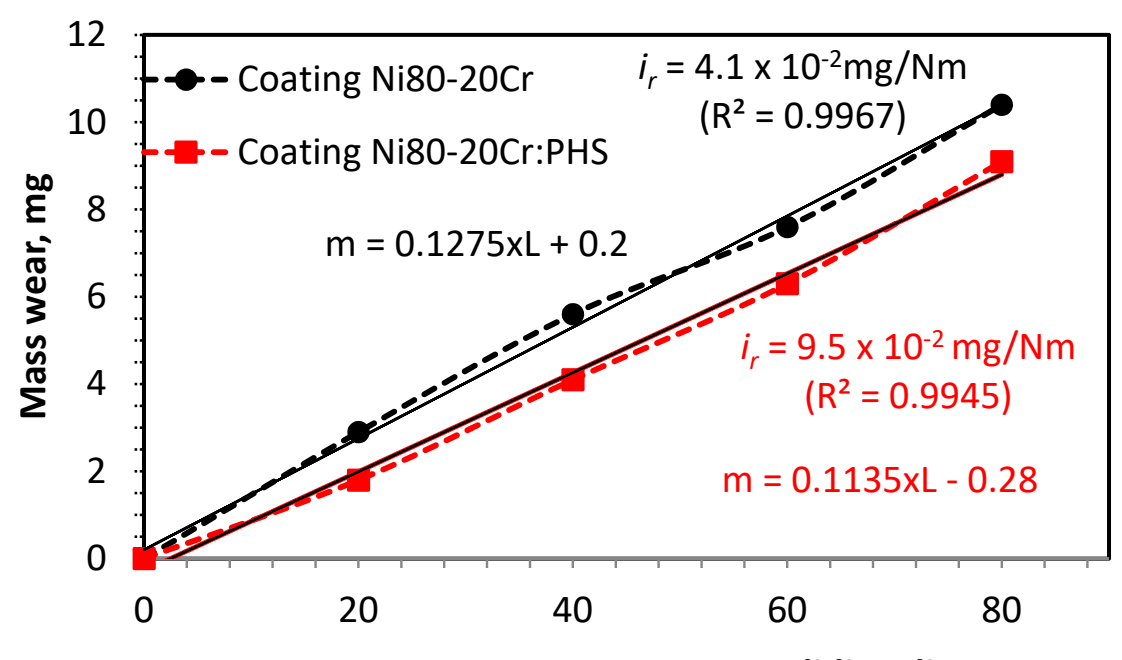

Figure 7. Mass wear vs. sliding distance for Ni80-20Cr and Ni80-20Cr: PHS coatings.

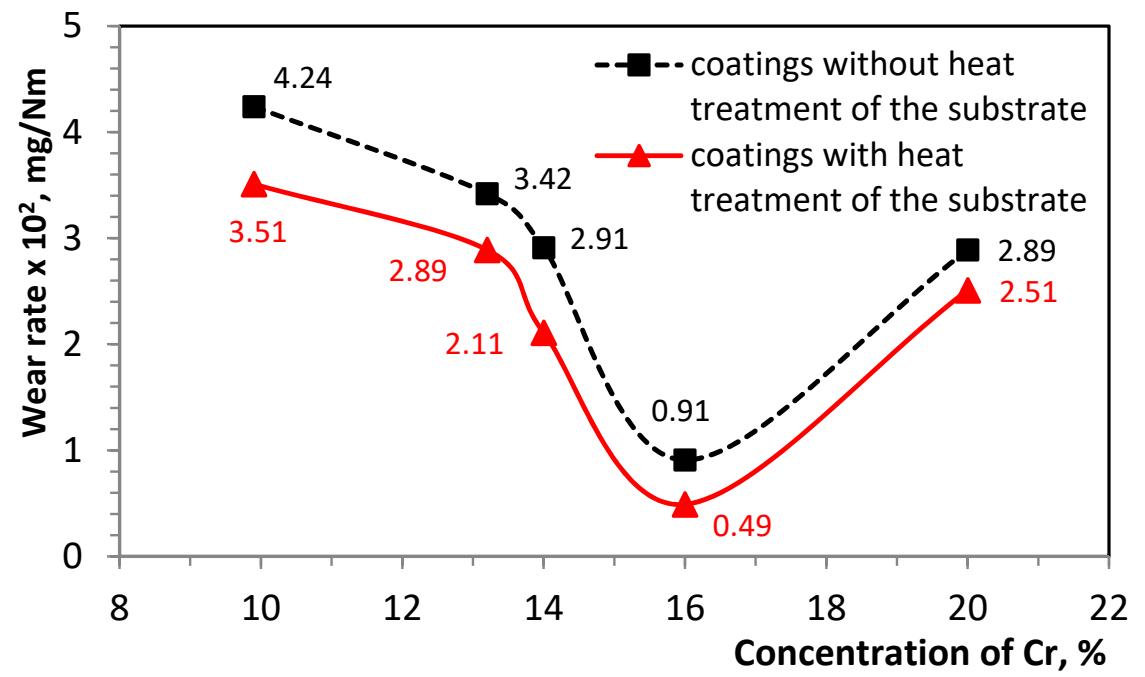

Figure 8. Dependence of wear rate on the concentration of chromium in the tested HVOF-coatings. 
The curve of the dependence of the wear resistance on the concentration of chromium in coatings without thermal treatment and with thermal treatment of the substrate is reciprocal to the curve of wear intensity (Figure 9).

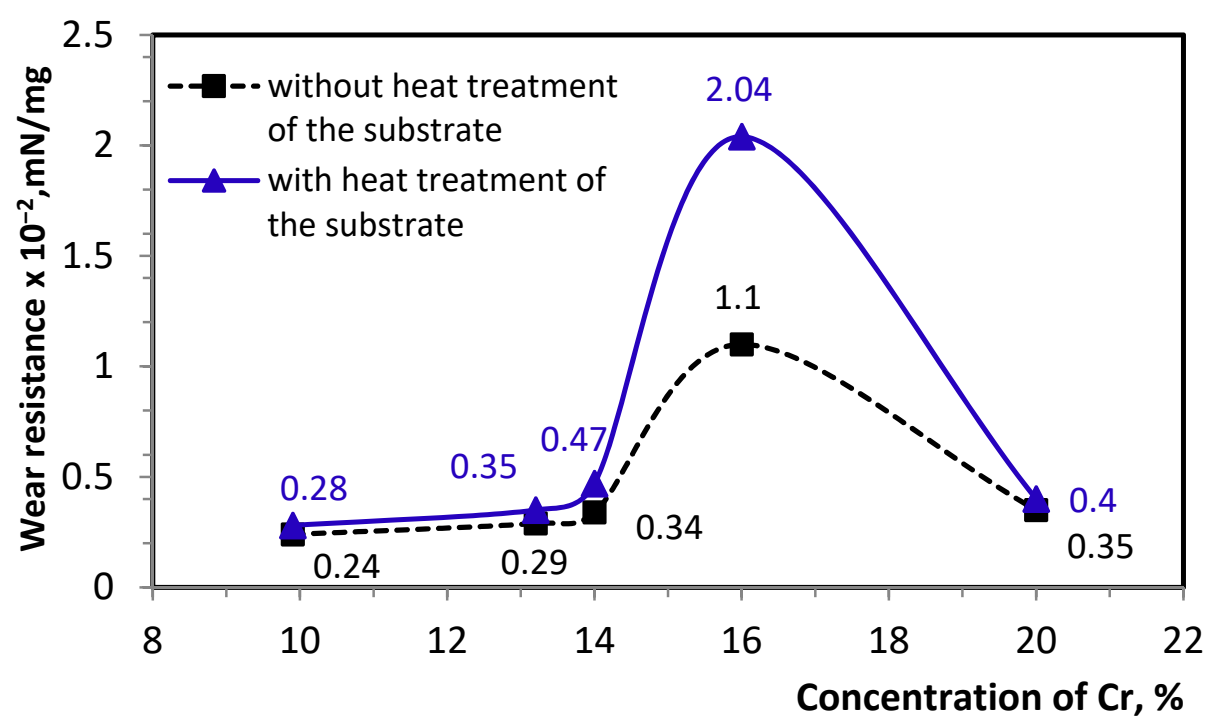

Figure 9. Dependence of wear resistance on the concentration of chromium in the tested HVOF coatings.

Figure 10 shows the diagram of the wear resistance of all the tested coatings, which gives clear evidence, that the lowest wear resistance is displayed by coatings having the lowest concentration of chromium without thermal treatment of the substrate $i_{r}=0.24 \times 10^{2} \mathrm{Nm} / \mathrm{mg}$, while the greatest wear resistance is manifested by the coatings having $16 \%$ content of chromium with thermal treatment of the substrate $I_{r}=2.04 \times 10^{2} \mathrm{Nm} / \mathrm{mg}$.

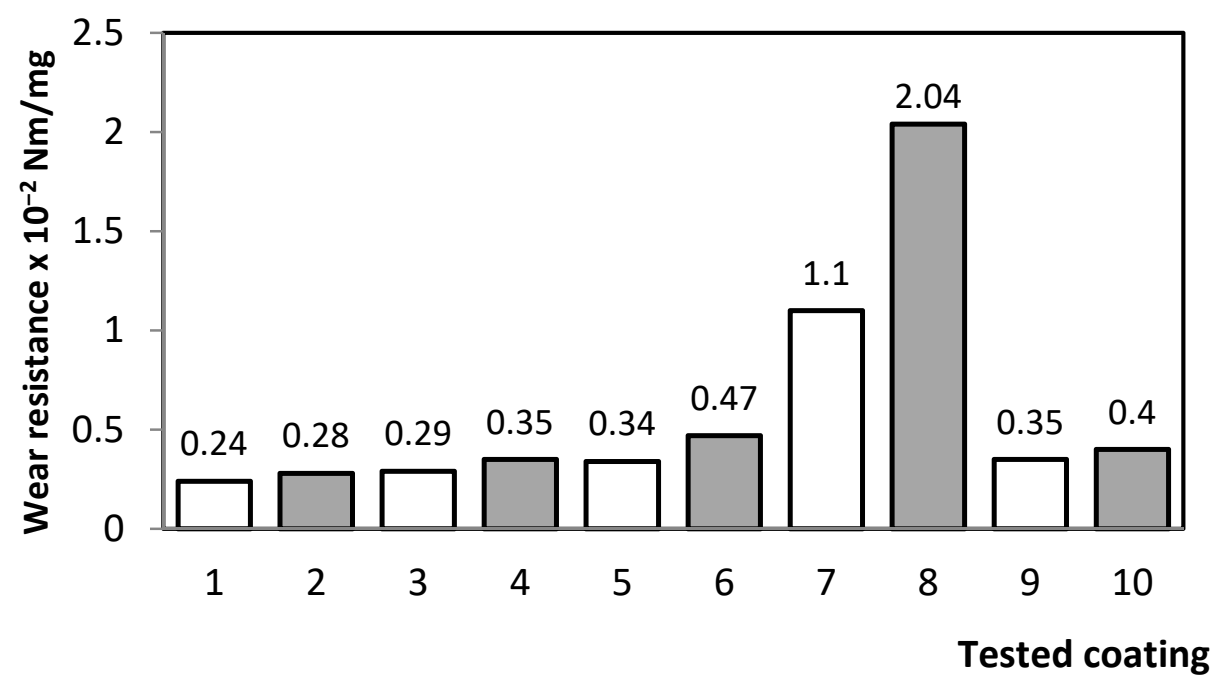

Figure 10. Diagram of the abrasive wear resistance of the tested coatings.

Table 4 represents results on the relative wear resistance, calculated by the Formula (4). The last two columns reflect the results respectively for the influence of the thermal treatment of the substrate and the effect of chromium concentration in the powder composites. These results are represented in the form of diagrams in Figures 11 and 12. 
Table 4. Relative abrasive wear resistance of the tested coatings.

\begin{tabular}{|c|c|c|c|c|c|}
\hline \multirow[b]{2}{*}{ Series } & \multirow[b]{2}{*}{ Sample } & \multirow[b]{2}{*}{$\begin{array}{c}\text { Coating } \\
\text { Designation }\end{array}$} & \multirow[b]{2}{*}{$\begin{array}{l}\text { Wear Resistance, } \\
\mathrm{mN} / \mathrm{mg} \text { in the Sliding } \\
\text { Distance } 80 \mathrm{~m}\end{array}$} & \multicolumn{2}{|c|}{ Relative Abrasive Wear Resistance } \\
\hline & & & & $\begin{array}{l}\text { Influence of Heat } \\
\text { Treatment of the } \\
\text { Substrate }\end{array}$ & $\begin{array}{c}\text { Influence of the } \\
\text { Concentration of } \mathrm{Cr}, \%\end{array}$ \\
\hline \multirow{2}{*}{ A } & 1 & NiBSi-9.9Cr & $0.24 \times 10^{2}$ & $\mathrm{R}_{1,1}=1$ & $\mathrm{R}_{1,1}=1$ \\
\hline & 2 & NiBSi-9.9Cr:PHS & $0.28 \times 10^{2}$ & $\mathrm{R}_{2,1}=1.17$ & $\mathrm{R}_{2,2}=1$ \\
\hline \multirow{2}{*}{ B } & 3 & NiBSi-13.2Cr & $0.29 \times 10^{2}$ & $\mathrm{R}_{3,3}=1$ & $\mathrm{R}_{3,1}=1.21$ \\
\hline & 4 & NiBSi-13.2Cr:PHS & $0.35 \times 10^{2}$ & $\mathrm{R}_{4,3}=1.21$ & $\mathrm{R}_{4,2}=1.25$ \\
\hline \multirow{2}{*}{$\mathrm{C}$} & 5 & NiBSi-14Cr & $0.34 \times 10^{2}$ & $\mathrm{R}_{5,5}=1$ & $\mathrm{R}_{5,1}=1.42$ \\
\hline & 6 & NiBSi-14Cr:PHS & $0.47 \times 10^{2}$ & $\mathrm{R}_{6,5}=1.38$ & $\mathrm{R}_{6,2}=1.68$ \\
\hline \multirow{2}{*}{$\mathrm{D}$} & 7 & NiBSi-16Cr & $1.10 \times 10^{2}$ & $\mathrm{R}_{7,7}=1$ & $\mathrm{R}_{7,1}=4.58$ \\
\hline & 8 & NiBSi-16Cr:PHS & $2.04 \times 10^{2}$ & $\mathrm{R}_{8,7}=1.84$ & $\mathrm{R}_{8,2}=7.29$ \\
\hline \multirow{2}{*}{$\mathrm{E}$} & 9 & $\mathrm{Ni} 80-20 \mathrm{Cr}$ & $0.35 \times 10^{2}$ & $\mathrm{R}_{9,9}=1$ & $\mathrm{R}_{9,1}=1.46$ \\
\hline & 10 & Ni80-20Cr:PHS & $0.40 \times 10^{2}$ & $\mathrm{R}_{10,9}=1.14$ & $\mathrm{R}_{10.2}=1.67$ \\
\hline
\end{tabular}

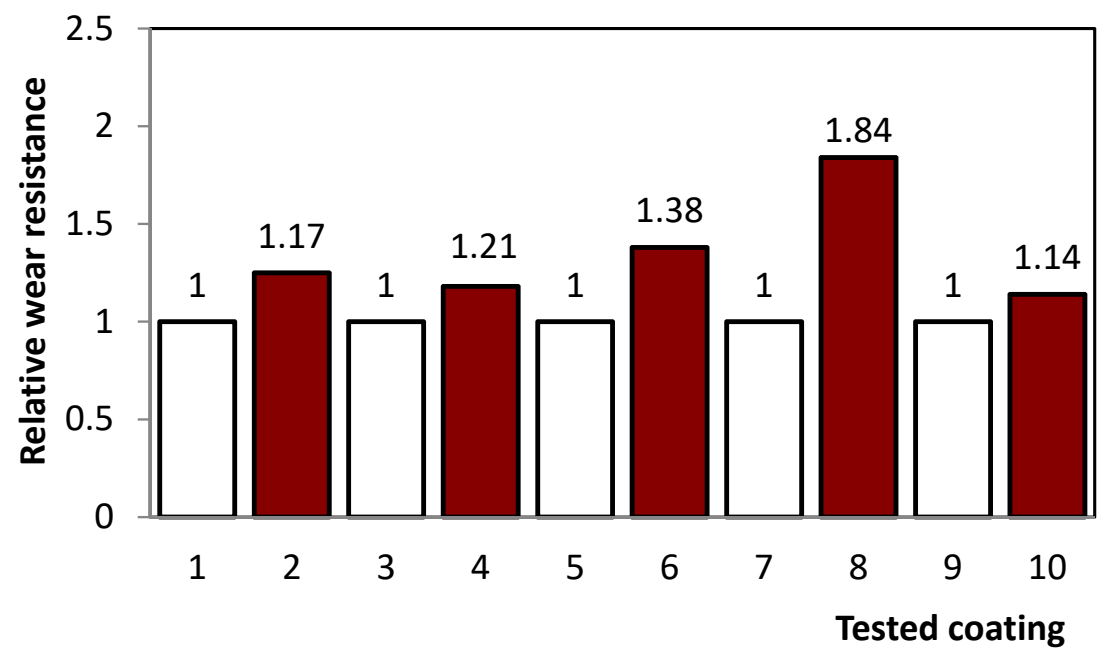

Figure 11. Diagram of the influence of the heat treatment of the substrate on the wear resistance of the tested coatings.

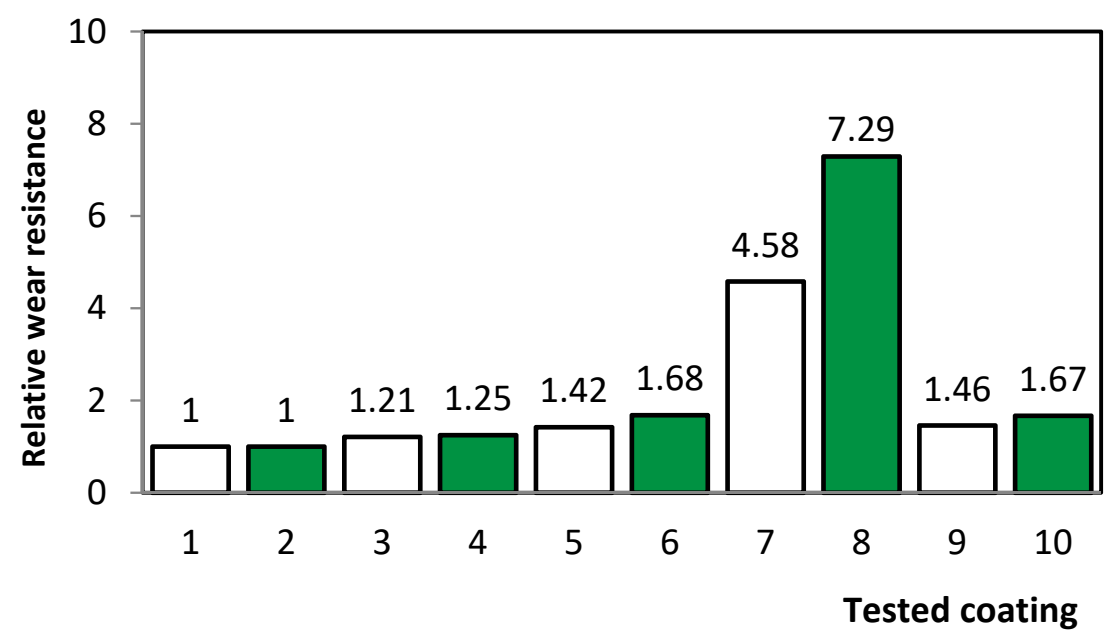

Figure 12. Diagram of the influence of $\mathrm{Cr}$ concentration on the wear resistance of the tested coatings. 
The strongest influence on the wear resistance is observed for the thermal treatment of the substrate in the case of the coating NiBSi-16Cr:PHS, having concentration of chromium at $16 \%$, for which the wear resistance is 1.84 times higher than that of the same coating without thermal treatment of the support. Next to it, follows the coating NiBSi-14Cr:PHS with concentration of chromium at $14 \%$. For the remaining coatings the influence of the thermal treatment is almost one and the same ranging from 1.14 to 1.21 .

The influence of the concentration of chromium upon the abrasive wear resistance of the coatings is the greatest in the cases of the coatings NiBSi-16Cr:PHS and NiBSi-16Cr $(16 \%$ $\mathrm{Cr}$ ). For coating with thermal treatment (the coating NiBSi-16Cr:PHS) the wear resistance is increased 7.29 times, while for the same coating without thermal treatment (the coating NiBSi-16Cr) it is increased 4.58 times, which is an extraordinary result. Another good result is the increase in the wear resistance of the coatings NiBSi-16Cr:PHS and Ni80-20Cr:PHS, which becomes higher almost to the same degree, respectively 1.68 and 1.67 times. The results on the wear resistance correlate with the hardness of the coatings having different concentrations of $\mathrm{Cr}$ (Figure 13).

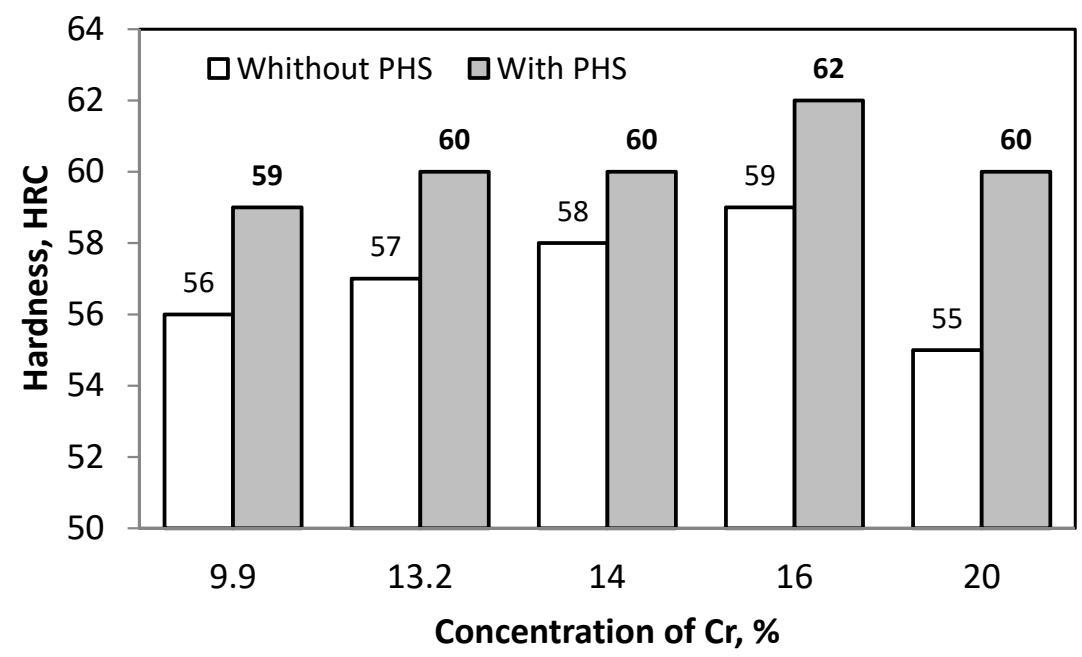

Figure 13. Diagram of the influence of $\mathrm{Cr}$ concentration on the hardness of the tested coatings.

Figure 14 illustrates the diagram of the interconnection between the abrasive wear resistance and the hardness of the tested coatings.

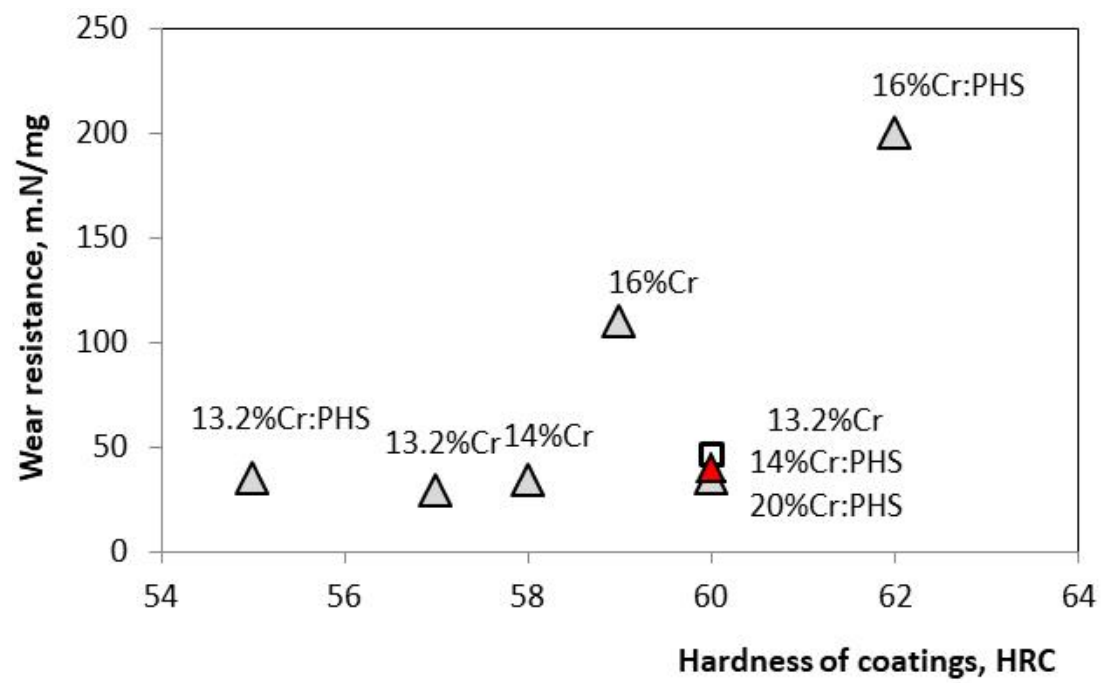

Figure 14. Diagram of abrasive wear resistance and hardness of the tested coatings. 


\section{Regression Models}

The experimental curve of the dependence of the wear intensity $i_{r}$ on the chromium concentration in the range $9.9 \% \leq w \leq 16 \%$ is considered (Figure 14).

The section of the curve where $w>16 \%$ is not considered because it includes coatings No 9 and No 10 (Ni80-20Cr and Ni80-20Cr:PHS) with different chemical composition from the other coatings. These coatings contain only nickel $(80 \%)$ and chromium $(20 \%)$, which does not give us reason to analyze them in parallel with the other coatings.

Experimental results for the wear intensity at more points on the curve in Figure 8 are presented in Table 5. Graphically, the dependence of the wear intensity on the percentage of chromium is shown in Figure 15.

Table 5. Wear rate at different chromium concentration, \%.

\begin{tabular}{ccccccc}
\hline $\boldsymbol{w}$, Concentration of $\mathbf{C r}, \mathbf{( \% )}$ & 9.9 & 11.8 & 13.2 & 14.0 & 15.2 & 16.0 \\
\hline $\begin{array}{c}i_{r}, \text { wear rate, } \mathbf{m g} / \mathbf{N m}, \text { without } \\
\text { heat treatment of the substrate }\end{array}$ & 4.24 & 3.82 & 3.42 & 2.91 & 2.1 & 0.91 \\
\hline $\begin{array}{c}i_{r}, \text { wear rate, } \mathbf{m g} / \mathbf{N m} \text {, with heat } \\
\text { treatment of the substrate }\end{array}$ & 3.51 & 3.35 & 2.89 & 2.11 & 1.35 & 0.49 \\
\hline
\end{tabular}

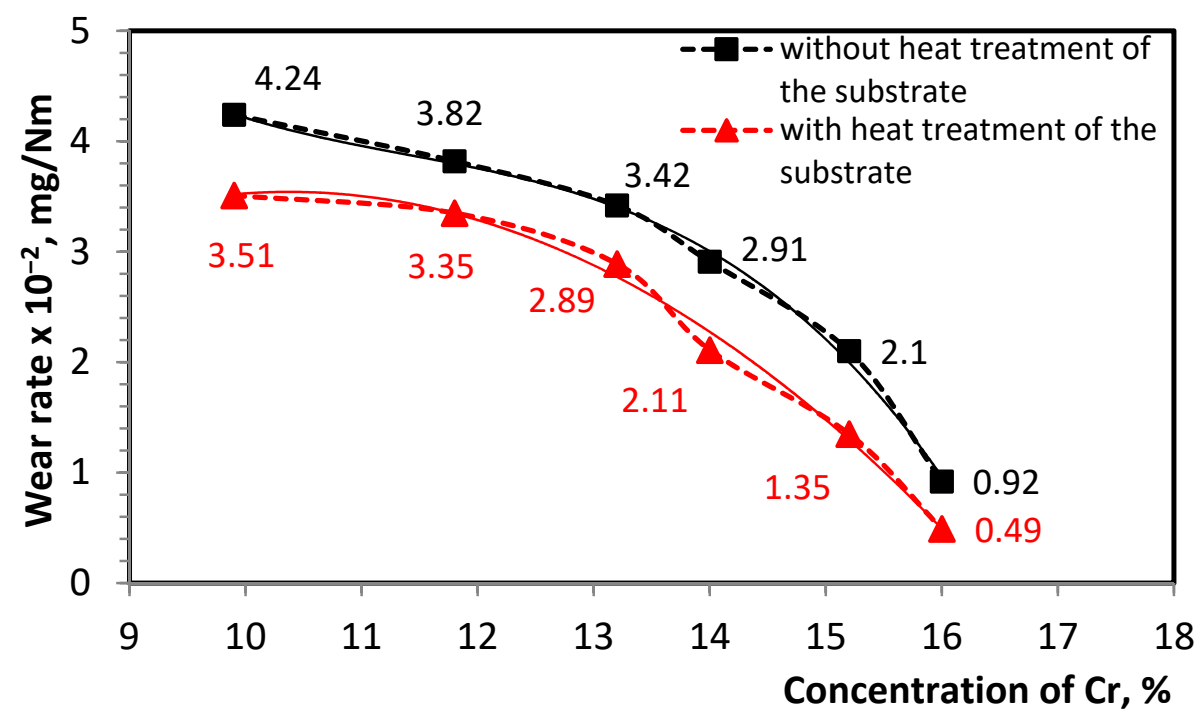

Figure 15. Dependence of wear rate on chromium concentration range from $9.9 \%$ to $16 \%$.

Based on the regression analysis, analytical dependences of the wear rate on the chromium concentration were obtained, presented as second- and third-degree polynomials.

For coatings without heat treatment of the substrate the dependence has the following form

$$
i_{r}(w)=a_{3} w^{3}+a_{2} w^{2}
$$

The results are presented on the next Figure 16.

The Adjusted R Square is 0.745894827 and shows that $74.58 \%$ of the variance of the intensity of wear is predictable from chosen factors $\left(w^{3}, w^{2}\right)$ which are adequately included in the model. The value of the significance $F$ with significance level 0.05 is $0.00012<0.05$ $(0.012 \%<5 \%)$, i.e., the results are reliable (statistically significant) and the model is adequate. $p$-values of the coefficients of the regression equations with level of significance 0.05 are smaller than 0.000032 , i.e., they are smaller than 0.05 , which means that the coefficients are statistically significant, and the adequacy of the model is confirmed. 


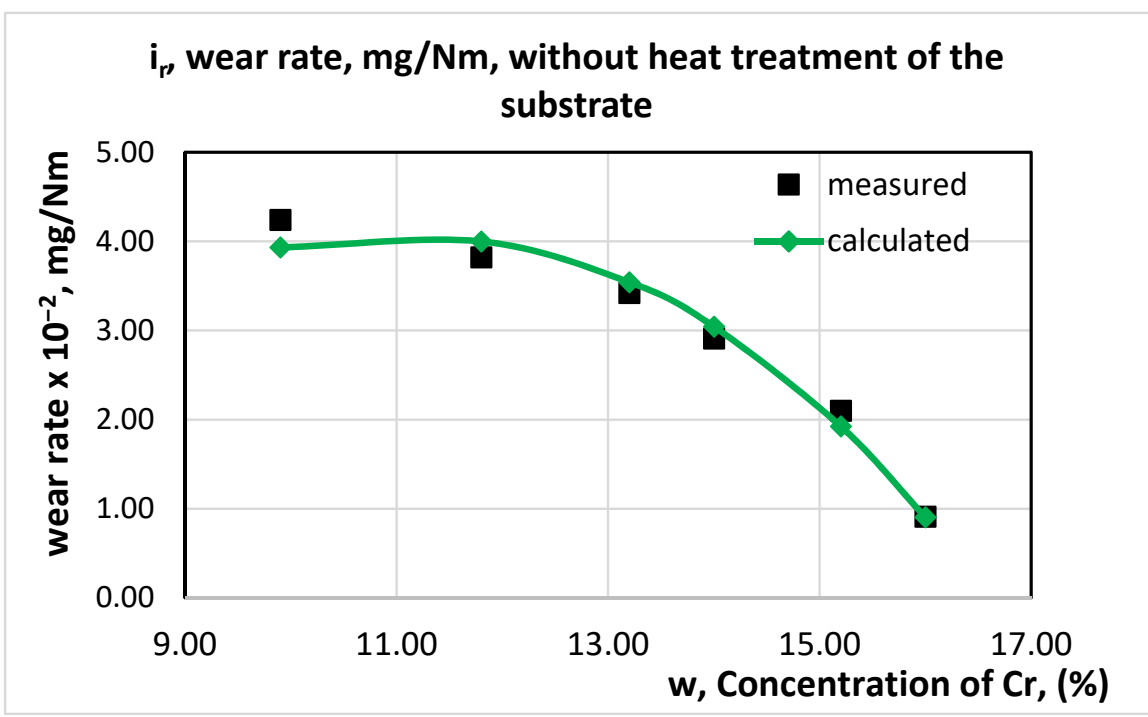

Figure 16. Analytical dependences of the wear rate on the chromium concentration for coatings without heat treatment, $i_{r}(w)=-0.00599819 w^{3}+0.099501902 w^{2}$.

For coatings without heat treatment of the substrate the dependence has the following form:

$$
i_{r}(w)=b_{3} w^{3}+b_{2} w^{2}
$$

The results are presented on the Figure 17.

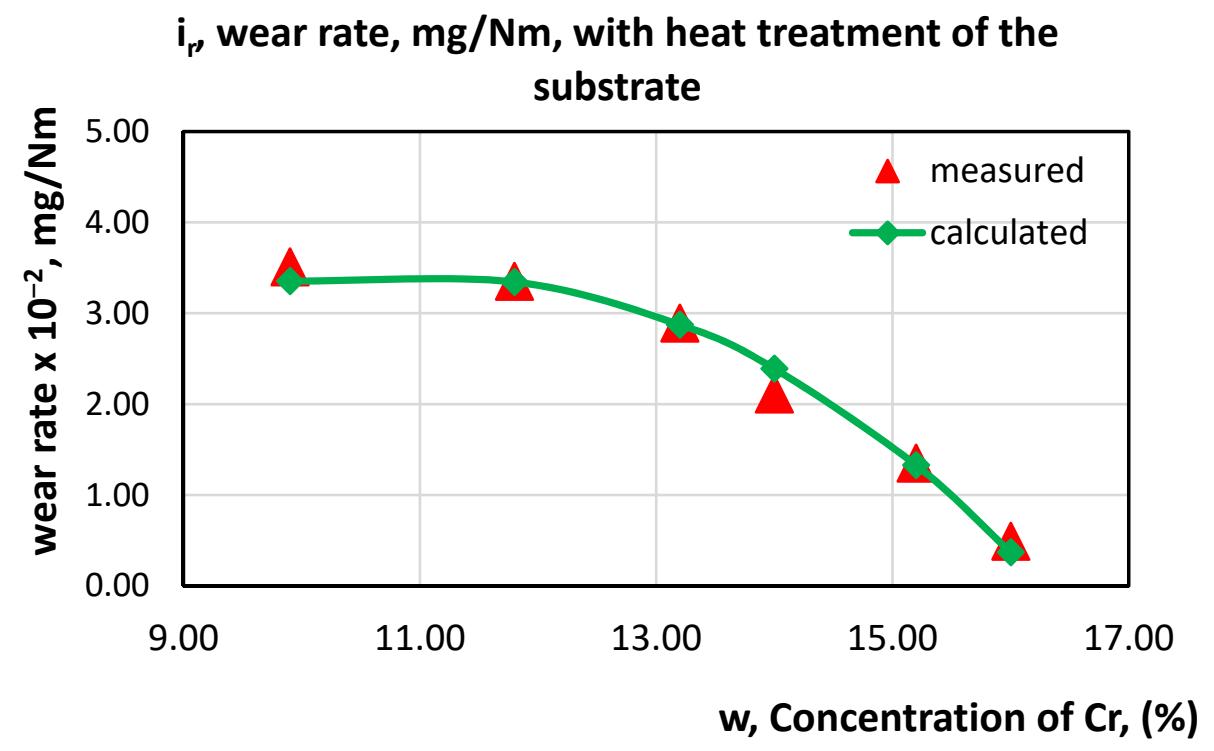

Figure 17. Analytical dependences of the wear rate on the chromium concentration for coatings with heat treatment, $i_{r}(w)=-0.005371987 w^{3}+0.087400503 w^{2}$.

The Adjusted R Square is 0.74616892 and shows that $74.62 \%$ of the variance of the intensity of wear is predictable from chosen factors $\left(w^{3}, w^{2}\right)$, i.e., they are adequately included in the model. The value of the significance $\mathrm{F}$ with significance level 0.05 is $0.00011<0.05(0.011 \%<5 \%)$, i.e., the results are reliable (statistically significant) and the model is adequate. P-values of the coefficients of the regression equations with level of significance 0.05 are smaller than 0.000019 , i.e., they are smaller than 0.05 , which means that the coefficients are statistically significant, and the adequacy of the model is confirmed. 


\section{Conclusions}

The present research work represents comparison of results for the characteristics of the wear process and the wear resistance of composite powder coatings, deposited by means of supersonic flame jet (HVOF), which contain composite mixtures $\mathrm{Ni}-\mathrm{Cr}-\mathrm{B}-\mathrm{Si}$ having different concentrations of chromium-9.9\%,13.2\%,14\%,16\%, and $20 \%$-at one and the same size of the particles $(45 \mu \mathrm{m})$ and equal content of the other elements, boron and silicon. The coating, prepared to have $20 \% \mathrm{Cr}$, does not contain the elements B and $\mathrm{Si}$. Each powder composition was applied to obtain coating without preliminary thermal treatment of the substrate and with preliminary thermal treatment of the substrate up to $650{ }^{\circ} \mathrm{C}$. The coatings have been tested under identical regimes of dry friction along the surface with firmly attached abrasive particles using a tribo-tester "Pin-disc".

Results have been obtained on the dependence of the mass wear as a function of the length of the pathway of friction, the variation of the wear rate depending on the concentration of chromium for coatings without thermal treatment of the substrate and with thermal treatment of the substrate.

It has been ascertained that for all coatings the preliminary thermal treatment of the substrate leads to a decrease in the wear rate.

It has been shown that upon increasing the concentration of chromium the wear rate is decreasing non-linearly, whereupon it reaches minimal values at $16 \% \mathrm{Cr}$. In the case of coatings having $20 \%$ concentration of $\mathrm{Cr}$ the wear rate is higher, which is due to the absence of the components $\mathrm{B}$ and $\mathrm{Si}$ in the composite mixture. In this case no new inter-metallic structures are formed, having high hardness and high wear resistance. A diagram of the interconnection between the hardness of the coatings and their abrasive wear resistance is represented.

The destruction of the surface of the coating due to abrasive wear is mechanical in nature. The main mechanisms of abrasive wear are two-plastic deformation and microcutting. At a low concentration of chromium in the coating, its hardness is lower, the abrasive particles penetrate into the coating, and initially, part of the material is pushed out, forming scratches and grooves on the surface of the coating. Due to the repeated cyclic interaction, the material separates from the surface and the intensity of wear increases as a result of the formation of submicro- and micro-cracks from fatigue. With a higher chromium content in the coating, the hardness of the coating is higher than the presence of chromium intermetalloid compounds. In this case, the abrasive wear takes place by the mechanism of micro-cutting of the surface layer of the coating, in which very thin and shallow scratches are observed and the wear rate is significantly lower.

Based on the regression analysis, analytical dependences of the wear rate on the chromium concentration were obtained for coatings without heat treatment and coatings with heat treatment of the substrate, presented as polynomials of second and third degree.

Author Contributions: Conceptualization, Z.K. and M.K.; methodology, M.K.; software, Y.S.; validation, Z.K., M.K. and Y.S.; formal analysis, Z.K.; investigation, M.K.; resources, Z.K.; data curation, Y.S.; writing-original draft preparation, M.K.; writing—review and editing, Z.K.; visualization, M.K.; supervision, M.K.; project administration, M.K.; funding acquisition, Z.K. All authors have read and agreed to the published version of the manuscript.

Funding: This research received no external funding.

Institutional Review Board Statement: Not applicable.

Informed Consent Statement: Not applicable.

Data Availability Statement: Not applicable.

Conflicts of Interest: The authors declare no conflict of interest. 


\section{References}

1. Pawlowski, L. The Science and Engineering of Thermal Spray Coatings; John Wiley\&Sons: Hoboken, NJ, USA, 2008.

2. Holmberg, K.; Matthews, A. Coatings Tribology: Properties, Mechanisms, Techniques and Applications in Surface Engineering; Elsevier: Amsterdam, The Netherlands, 2009.

3. Bhushan, B. Nanortibology, Nanomechanics and Materials Characterization Studies and Application to Bio/Nanotechnology and Biomimetics. In Proceedings of the Serbiatrib'11, Kragujevac, Serbia, 11-13 May 2011.

4. Stachowiak, G.; Batchelor, A.W. Engineering Tribology; Butterworth-Heinemann: Boston, MA, USA, 2000.

5. Vencl, A. Optimization of the Deposition Parameters of Thick Atmospheric Plasma Spray Coatings. J. Balk. Tribol. Assoc. 2012, $18,405-414$.

6. Kandeva, M.; Peichev, I.; Kostova, N.; Stoichkov, K. Complex Study of Surface layers and Coatings. J. Balk. Tribol. Assoc. 2011, 17, 387-393.

7. Petrov, T.; Tashev, P.; Kandeva, M. Wear Resistance of Surface Layers Modified with $\mathrm{AL}_{2} \mathrm{O}_{3}$ and TiCN Nanopowders Weld Overlaid Using TIG and ITIG Methods. J. Balk. Tribol. Assoc. 2016, 22, 304-315.

8. Tashev, P.; Lazarova, R.; Kandeva, M.; Petrov, R.; Manolov, V. Tungsten Inert Gas Weld Overlay Using Nano-Sized Tin Powder. J. Balk. Tribol. Assoc. 2016, 22, 2916-2932.

9. Dimitrova, R.; Kandeva, M.; Kamburov, V.; Jordanov, M. Mechanical and Tribological Characteristics of Hardfaced Dispersive Reinforced Aluminium Metal Matrix Layers. J. Balk. Tribol. Assoc. 2017, 23, 641-652.

10. Kandeva, M.; Penyashki, T.; Kostadinov, G.; Kalitchin, Z.; Kaleicheva, J. Wear of Electroless Nickel-Phosphorus Composite Coatings with Nanodiamond Particles. J. Environ. Prot. Ecol. 2018, 19, 1200-1214.

11. Kandeva, M.; Kamburov, V.; Zadorozhnaya, E.; Kalitchin, Z. Abrasion Wear of Electroless Nickel Composite Coatings Modified with Boron Nitride Nanoparticles. J. Environ. Prot. Ecol. 2018, 19, 1690-1703.

12. Kovac, P.; Jesic, D.; Sovilj-Nikic, S.; Kandeva, M.; Kalitchin, Z.; Gostimirovic, M.; Savkovic, B. Energy Aspects of Tribological Behaviour of Nodular Cast Iron. J. Environ. Prot. Ecol. 2018, 19, 163-172.

13. Kandeva, M.; Grozdanova, T.; Karastoyanov, D.; Assenova, E. Wear Resistance of WC/Co HVOF-Coatings and Galvanic Cr Coatings Modified by Diamond Nanoparticles. In Proceedings of the 13th International Conference on Tribology ROTRIB'16, Galați, Romania, 22-24 September 2016; IOP Conference Series: Materials Science and Engineering. 2017; Volume 174, p. 012060. [CrossRef]

14. Kandeva, M.; Balabanov, V.; Zadorozhnaya, E.; Kalitchin, Z.; Svoboda, P. Environmental Protection by Self-Organisation of Tribosystems with Self-Lubricating Materials in Dry Friction: Part I. Investigations at different loads. J. Environ. Prot. Ecol. 2017, $18,1050-1069$.

15. Kandeva, M.; Balabanov, V.; Zadorozhnaya, E.; Kalitchin, Z.; Svoboda, P.; Levanov, I. Environmental Protection by SelfOrganisation of Tribosystems with Self-Lubricating Materials in Dry Friction. Part II: IInvestigations at Different Dry Sliding Rates. J. Environ. Prot. Ecol. 2017, 18, 1581-1592.

16. Kandeva, M.; Svoboda, P.; Nikolov, N.; Todorov, T.; Sofronov, Y.; Pokusová, M.; Vencl, A. Effect of Silicon Carbide Nanoparticles Size on Friction Properties of Electroless Nickel Coatings. J. Environ. Prot. Ecol. 2020, 21, 1314-1325.

17. Kandeva, M.; Kamburov, V.; Nikolov, K.; Dimitrov, L. Abrasive Wear of Ultra-High-Molecular-Weight Polyethylene Modified with Carbon Nanotubes. J. Balk. Tribol. Assoc. 2020, 26, 272.

18. Kandeva, M.; Stoimenov, N.; Popov, B.; Kalitchin, Z.; Pozhidaeva, V. Abrasive Wear Resistance of Micro- and Nano-Diamond Particles. J. Balk. Tribol. Assoc. 2020, 26, 181.

19. Dyakova, V.; Tashev, P.; Kandeva, M. Study on the Effect of Nanosized Particles of Tin and SiC on the Wear Resistance, Microstructure and Corrosion Behavior of Overlay Weld Metal. J. Balk. Tribol. Assoc. 2020, 26, 56-65.

20. Alaci, S.; Irimescu, L.; Ciornei, F.; Kandeva, M. Device and Method for Simultaneous Determination of Rolling and Spinning Friction in a Concentrated Contact. J. Balk. Tribol. Assoc. 2020, 26, 1-10.

21. Kandeva, M.; Rozhdestvensky, Y.; Svoboda, P.; Kalitchin, Z.; Zadorozhnaya, E. Influence of the Size of Silicon Carbide Nanoparticles on the Abrasive Wear of Electroless Nickel Coatings. Part 1. J. Environ. Prot. Ecol. 2019, 20, 1889-1903.

22. Kandeva, M.; Rozhdestvensky, Y.; Svoboda, P.; Kalitchin, Z.; Zadorozhnaya, E. Influence of the Size of Silicon Carbide Nanoparticles on the Abrasive Wear of Electroless Nickel Coatings. Part 2. J. Environ. Prot. Ecol. 2020, 21, 222-233.

23. Kandeva, M.; Kalitchin, Z.H.; Svoboda, P.; Sovilj-Nikic, S. General Methodology for Studying the Tribological Processes on the Basis of the Communicative Potential. J. Balk. Tribol. Assoc. 2019, 25, 432-442.

24. Oksa, M.; Turunen, E.; Suhonen, T.; Varis, T.; Hannula, S. Optimization and Characterization of High Velocity Oxy-Fuel Sprayed Coatings, Techniques, Materials and Applications. Coatings 2011, 1, 17-52. [CrossRef]

25. Mrdak, M.R.; Vencl, A.; Nedeljković, B.D.; Stanković, M. Influence of Plasma Spraying Parameters on Properties of the Thermal Barrier Coatings. Mater.Sci. Technol. 2013, 29, 559-567. [CrossRef]

26. Wood, R.J.K.; Roy, M. Tribology of Thermal_Sprayed Coatings (Surface Engineering for Enhanced Performance against Wear); Roy, M., Ed.; Springer: Wien, Austria, 2013; pp. 1-43.

27. Cabral-Miramontes, J.A.; Gaona-Tiburcio, C.; Almeraya-Calderón, F.; Estupiñan-Lopez, F.H.; Pedraza-Basulto, G.K.; PoblanoSalas, C.A. Parameter studies on high-velocity oxy-fuel spraying of CoNiCrAlY coatings used in theater on autical industry. Int. J. Corros. 2014, 2014, 703806. [CrossRef]

28. Chivavibul, P.; Watanabe, M.; Kuroda, S.; Kawakita, J.; Komatsu, M.; Sato, K.; Kitamura, J. Effect of powder characteristics on properties of warm-sprayed WC-Co coatings. J. Therm. Spray Technol. 2003, 19, 81-88. [CrossRef] 
29. Liu, Y.; Fischer, T.E.; Dent, A. Comparison of HVOF and Plasma-sprayed Alumina/titania coatings-Microstructure, Mechanical Properties and Abrasion Behaviour. Surf. Coat. Technol. 2013, 167, 68-76. [CrossRef]

30. Kandeva, M.; Grozdanova, T.; Karastoyanov, D.; Ivanov, P.; Kalitchin, Z. Tribology Study of High-Technological Composite Coatings Applied Using High Velocity Oxy-Fuel. In Proceedings of the 9th International Conference on Tribology (Balkantrib 2017), Nevsehir, Turkey, 13-15 September 2017; IOP Conference Series: Materials Science and Engineering. 2018; Volume 295, p. 012025.

31. Kandeva, M.; Ivanova, B.; Karastoyanov, D.; Grozdanova, T.; Assenova, E. Abrasive Wear of High Velocity Oxygen Fuel (HVOF) Superalloy Coatings under Vibration Load. In Proceedings of the 13th International Conference on Tribology ROTRIB'16, Galati, Romania, 22-24 September 2016; IOP Conference Series: Materials Science and Engineering. 2017; Volume 174, p. 012010. [CrossRef]

32. Kandeva, M.; Zadorozhnaya, E.; Kalitchin, Z.; Svoboda, P. Tribological Studies Of High Velocity Oxy-Fuel (HVOF) Superalloy Coatings. J. Balk. Tribol. Assoc. 2018, 24, 411-428.

33. Kandeva, M.; Svoboda, P.; Kalitchin, Z.; Penyashki, T.; Kostadinov, G. Wear of Gas-Flame Composite Coatings with Tungsten and Nickel Matrix. Part, I. Abrasive Wear. J. Environ. Prot. Ecol. 2019, 20, 811-822.

34. Penyashki, T.; Kostadinov, G.; Radev, D.; Kandeva, M. Comparative Studies of Tribological Characteristics of Carbon Steels with Gas Flame Coatings from New Multi-component Carbide Composite Materials. Oxid. Commun. 2019, 42, 74-89.

35. Czupryński, A. Properties of Al2O3/TiO2 and ZrO2/CaO flame sprayed coatings. Spajanie Mater. Konstr. 2017, 2, 32-39.

36. Czupryński, A.; Górka, J.; Adamiak, M.; Tomiczek, B. Testing of Flame Sprayed $\mathrm{Al}_{2} \mathrm{O}_{3} \mathrm{Matrix}_{\text {Coatings Containing TiO}}$. Arch. Metall. Mater. 2016, 61, 1363-1370. [CrossRef]

37. Czupryński, A. Flame spraying of aluminum coatings reinforced with particles of carbonaceous materials as an alternative for laser cladding technologies. Materials 2019, 12, 3467. [CrossRef]

38. Liao, H.; Normand, B.; Coddet, C. Influence of coating microstructure on the abrasive wear resistance of WC/Co cermet coatings. Surf. Coat. Technol. 2000, 124, 235-242. [CrossRef]

39. Magnani, M.; Suegama, P.H.; Espallargas, N.; Dosta, S.; Fugivara, C.S.; Guilemany, J.M.; Benedetti, A.V. Influence of HVOF parameters on the corrosion and wear resistance of WC-Co coatings sprayed on AA7050 T7. Surf. Coat. Technol. 2008, 202, 4746-4757. [CrossRef]

40. Janka, L.; Norpoth, J.; Trache, R.; Thiele, S.; Berger, L.-M. HVOF- and HVAF-Sprayed $\mathrm{Cr}_{3} \mathrm{C}_{2}$-NiCr Coatings Deposited from Feedstock Powders of Spherical Morphology: Microstructure Formation and High-Stress Abrasive Wear Resistance Up to $800{ }^{\circ} \mathrm{C}$. J. Therm. Spray Technol. 2017, 26, 1720-1731. [CrossRef]

41. Poirier, D.; Legoux, J.-G.; Lima, R.S. Engineering HVOF-Sprayed $\mathrm{Cr}_{3} \mathrm{C}_{2}-\mathrm{NiCr}$ Coatings: The Effect of Particle Morphology and Spraying Parameters on the Microstructure, Properties, and High Temperature Wear Performance. J. Therm. Spray Technol. 2013, 22, 280-289. [CrossRef] 